Available online at www.banglajol.info

Bangladesh J. Sci. Ind. Res. 47(4), 449-452, 2012

Short Communication
BANGLADESH JOURNAL OF SCIENTIFIC AND INDUSTRIAL RESEARCH

E-mail: bjsir07@gmail.com

\title{
Mudskipper, periophthalmodon schlosseri (pallas) from the Naf river
}

\author{
B. K. Saha \\ Department of Zoology, Netrakona Govt. College-2400, Netrokona, Bangladesh.
}

\begin{abstract}
A study on morphometrics, meristics sex ratio, ovary condition of Periophthalmodon schlosseri was conducted in 2001. The mean of total length $(49.63 \pm 5.99 \mathrm{~mm})$, standard length $(40.84 \pm 5.30 \mathrm{~mm})$, snout length $(4.12 \pm 0.65 \mathrm{~mm})$, head length $(9.86 \pm 1.39 \mathrm{~mm})$, height of body $(6.89 \pm 1.24 \mathrm{~mm})$ and the length of caudal peduncle $(6.96 \pm 1.08 \mathrm{~mm})$ were calculated. The length-weight relationship was determined as $\mathrm{TW}=0.00004639+2.5882 \mathrm{TL}$. The fin formula was $\mathrm{D}_{1} \cdot 8-9 ; \mathrm{D}_{2} \cdot 1 / 10-13 ; \mathrm{P}_{1} \cdot 11-14 ; \mathrm{P}_{2} .11-14 ; \mathrm{A} .1 / 11$. The sex ratio was found to be 1:0.63. The average of ovary length $(6.2 \pm 0.84 \mathrm{~mm})$, ovary breadth $(3.54 \pm 0.95 \mathrm{~mm})$ and diameter of ova $(0.22 \pm 0.04 \mathrm{~mm})$ were also determined.
\end{abstract}

Keywords: Inhabitant; Information; Biology; Taxonomic; Morphometrics

\section{Introduction}

Among the mudskippers, Periophthalmodon schlosseri is the inhabitant of coasts and tidal rivers of Bangladesh (Rahman 1989). Detailed information on biology of $P$. schlosseri has not been received in Bangladesh, except for some taxonomic works by Munro (1955), Rahman (1989), and Shafi and Quddus (2004). The objective of the present paper dealt with morphometrics, meristics, sex ratio and ovary condition of $P$. schlosseri collected from the Naf river.

\section{Materials and Methods}

A total number of 58 specimens of $P$. schlosseri was collected on 31 December, 2001 by hand picking method. The specimens were preserved in 5\% formalin. Lengths of the fishes were measured in the nearest $\mathrm{mm}$ by means of a measuring board fitted with a centimeter scale and their weights were recorded in $\mathrm{g}$ by means of a sensitive Pan Balance. Statistical formulae (Snedecor 1956 and Simpson et al. 1960) were applied to establish mathematical relationship between total length and other variables. The total length and total weight relationship of the fishes were determined by using the logarithmic transformation of the formula: $\mathrm{W}=$ $\mathrm{aL}^{n}$ (Le Cren 1951).

The fishes were differentiated into males and females after dissecting out the gonads.

\section{Results and discussion}

Morphometric study

The mean and range of total length, standard length, snout length, head length, the length of the peduncle, the height of body and the weight of body are presented in Table I. The length-weight relationship was calculated as $\mathrm{TW}=$ 0.00004639.TL2.5882. Rahman (1989) reported the total length of the species up to $220.0 \mathrm{~mm}$, but Shafi and Quddus (2004) recorded the maximum size as $328.5 \mathrm{~mm}$. Relationships between total length (TL) and standard length (SL), snout length (SnL), head length (HL), length of caudal peduncle (LCP), height of body (HB) and total weight (TW) of $P$. schlosseri are linear, positive and highly significant (Table I).

\section{Meristic study}

Meristic counts of $P$. schlosseri stand as follows: $\mathrm{D}_{1} \cdot 8-9 ; \mathrm{D}_{2}$ $. \mathrm{I} / 10-13 ; \mathrm{P}_{1}$. 11-14; $\mathrm{P}_{2}$. 11-14; A. 1/11. The report of Rahman (1989) is in accordance with this finding.

Sex ratio

The percentages of male and female of P.schlosseri were 61.54 and 38.46, respectively. Saha et al. (2006) determined the sex ratio of Rastrelliger kanagurta as 1:0.94. 
Table I. Relationship between TL and SL, SnL, HL, TW, CPL, HB, OL, OB and diameter of ova in P. schlosseri

\begin{tabular}{|c|c|c|c|c|}
\hline $\begin{array}{c}\text { Abscissa } \\
\text { range }(\text { mean } \pm \mathrm{SD})\end{array}$ & $\begin{array}{c}\text { Ordinate } \\
\text { range }(\text { mean } \pm \mathrm{SD})\end{array}$ & $\begin{array}{l}\text { Value of } \\
\text { 'a' }\end{array}$ & $\begin{array}{l}\text { Value of } \\
\text { 'b' }\end{array}$ & $\begin{array}{l}\text { Correlation } \\
\text { co-efficient ' } r \text { ' }\end{array}$ \\
\hline $\begin{array}{l}\mathrm{TL}(\mathrm{mm}) \\
38-70\end{array}$ & $\begin{array}{c}\mathrm{SL}(\mathrm{mm}) \\
29-57 \\
40.84 \pm 5.30\end{array}$ & -1.633 & 0.854 & 0.974 \\
\hline TL & $\begin{array}{c}\mathrm{SnL}(\mathrm{mm}) \\
3-6 \\
4.12 \pm 0.65\end{array}$ & -0.27 & 0.088 & 0.851 \\
\hline TL & $\begin{array}{c}\mathrm{HL}(\mathrm{mm}) \\
7-14 \\
9.86 \pm 1.39\end{array}$ & -0.195 & 0.202 & 0.877 \\
\hline $\mathrm{TL}$ & $\begin{array}{c}\mathrm{TW}(\mathrm{g}) \\
0.63-2.87 \\
1.20 \pm 0.42\end{array}$ & -2.087 & 0.066 & 0.938 \\
\hline TL & $\begin{array}{c}\mathrm{CPL}(\mathrm{mm}) \\
5-10 \\
6.931 .08\end{array}$ & -0.293 & 0.145 & 0.808 \\
\hline TL & $\begin{array}{c}\mathrm{HB}(\mathrm{mm}) \\
5-10 \\
6.89 \pm 1.24\end{array}$ & -0.105 & 0.141 & 0.688 \\
\hline TL & $\begin{array}{c}\mathrm{OL}(\mathrm{mm}) \\
5-7 \\
6.2 \pm 0.84\end{array}$ & -0.16 & 0.126 & 0.818 \\
\hline TL & $\begin{array}{c}\mathrm{OB}(\mathrm{mm}) \\
2.2-4.4 \\
3.540 .95\end{array}$ & -3.66 & 0.143 & 0.811 \\
\hline $\mathrm{TL}$ & $\begin{array}{c}\mathrm{DO}(\mathrm{mm}) \\
0.2-0.3 \\
0.22 \pm 0.044\end{array}$ & -0.158 & 7.534 & 0.910 \\
\hline
\end{tabular}

Ovary condition

The mean and range of ovary length, ovary breadth and diameter of ova are shown in Table I. Relationships between total length and ovary length, ovary breadth and ova diameter were straight, linear and highly significant (Table 1).

\section{References}

Le Cren ED (1951), The length-weight relationship and seasonal cycle in gonad weight and condition in the perch (Perca fluviatilis). J. Anim. Ecol., 20: 201-219. 
Munro ISR (1955), Marine and freshwater fishes of Ceylon. Department of External Affairs, Canberra, publ. I-XV, 134 pp. 55 plates.

Rahman AKA (1989), Freshwater fishes of Bangladesh. Zoological Society of Bangladesh, Dhaka, 364 pp.

Shafi M. and Quddus MMA (2004), Bangladesher Matsa Sampad (Fisheries of Bangladesh). Mahmud Hossain, Kabir publications, Banglabazar, Dhaka, 440 pp.
Saha BK, Islam MR, Khairunnessa, Saha A and Hossain MA (2006), Some aspects of biology of the Indian Mackerel, Rastrelliger kanagurta (Cuvier) (Perciformes: Scombridae) from Cox's Bazar. $J$. Asiat.Soc. Bangladesh (Sci.), 32(2):289-292.

Snedecor GW (1965), Statistical methods. Lowa State University Press, Amer. Lowa, 534 pp.

Simpson GG, Roe A and Lewontin RC (1960), Quantitative Zoology. Harcourt Brace \& Co., New York, 440 pp.

Received: 23 November 2010; Revised: 15 February 2011; Accepted: 10 March 2011. 